\title{
Strategies to improve water use efficiency in the crop production
}

\begin{abstract}
The increasing of water use effciency is very important to sabe irrigation water in agriculture in anscenery of risks by droughts and climate change. The aim of this minireview is highlight irrigation technologies and the some strategies of the irrigation wáter management. The manuscript analyze the effect of irrigation technologies, wáter policy, irrigation scheduling, system maintenance and technology transfer to obtain more biomass per unit of wáter applied
\end{abstract}

Keywords: waters carcity, transfer technoology, irrigation scheduling, wáter policy , climate change, maintenance
Volume 5 Issue I - 202I

\author{
Celerino Quezada Landeros \\ Soils and Natural Resources Department, Faculty of Agronomy, \\ University of Concepción, Chile
}

Correspondence: Celerino Quezada Landeros, Soils and Natural Resources Department, Faculty of Agronomy, University of Concepción, Chile, Email cequezad@udec.cl

Received: January 12, 2021 | Published: January 22, 202 |

\section{Introduction}

Agricultural production in the world is threatened for droughts, climate change and groundwaterdepletion. ${ }^{1}$ Water is a scarce resource and very competitive with productive sectors that are more profitable than agriculture, such as industry, tourism and mining, and conflicts arise between irrigation needs and human consumption. ${ }^{2}$ The aquifers have been overexploited with depletion the piezometric level, increasing the pumping costs. ${ }^{3}$

The quantity of water available for agriculture is declining in all regions of the world and there is little awareness about the sustainable management of hydric resources. On the other hand, the agriculture is criticized for the inefficient irrigation water use with large losses due to runoff and deep percolation. Besides, it's cause problems of salinization and contamination of aquifers with nitrates, phosphates and eutrophication in surface water. ${ }^{4}$ Therefore, it's very important use technologies of high efficiency localized irrigation, selection of drougth resistant crops and apply agronomical management technique to diminush the evapotranspiration.

\section{Agriculture water use}

The agriculture use about $80-90 \%$ of freshwater and so is key produce 'more crop per drop' with improvements in agronomic and physiological knowledge to increase the water productivity. ${ }^{5}$

Water will be the higher limitation for agriculture in coming decades, despite that agricultural policies prioritize increasing the irrigated area 6 but not the irrigation efficiency. The water used mainly for irrigation is faced with intense pressure to improve the WUE with other users who are being affected by climate change., ${ }^{6,7}$

There are other options for increase the water offer by reduce losses by percolation and run-off, increase water soil infiltration, subsurface irrigation, harvest runoff of water rainfall and construction of storage reservoirs. ${ }^{8}$

\section{Water use efficiency (WUE)}

WUE is defined as a relationship between biomass $(\mathrm{kg})$ and water use $\left(\mathrm{m}^{3}\right)$. Improvement of water use efficiency of crops and fruit strees is an imperative imposed by the critical situation of wáter resources in the world specially in mediterranean áreas.9The lower WUE in farmer's fields compared with well-managed experimental sites indicates that more efforts are needed to transfer water-saving technologies to the farmers ${ }^{10}$ by extensión and education services Some technologies of crop wáter managenent very important to improve WUE are :relationships between yield-evapo transpiration, regulated déficit irrigation (RDI) and partial root-zone drying (PRD), that permite wáter saving without production significative reduction. ${ }^{8,11,12}$

In this regard, a research in olive showed that is posible decrease the water applied without a decrease significative in yields obtaining higher WUE (Table 1). ${ }^{13}$ The decreasing of water application was $46.84 \%$, equivalent to $1609 \mathrm{~m}^{3}$ ha-1with WUE of $8.65 \mathrm{~kg} \mathrm{~m}^{-3}$.

Table I Water use efficiency in olive 'Arbequina' with differents hydric treatments basis Class A pan under drip irigation in an Ultic Palexeralfs soil, ñuble region, Chile

\begin{tabular}{llllll}
\hline $\begin{array}{l}\text { Hydric } \\
\text { treatment }\end{array}$ & $\begin{array}{l}\text { Class } \\
\text { A pan } \\
(\%)\end{array}$ & $\begin{array}{l}\text { Water } \\
\text { applied } \\
\left(\mathbf{m}^{3} \mathbf{h a}^{-1}\right)\end{array}$ & $\begin{array}{l}\text { Water } \\
\text { saving } \\
(\%)\end{array}$ & $\begin{array}{l}\text { Yield } \\
\left(\mathbf{k g ~ h a}^{-1}\right)\end{array}$ & $\begin{array}{l}\text { WUE } \\
\left(\mathbf{k g ~ m}^{-3}\right)\end{array}$ \\
\hline TI & 30 & 1002 & 70.83 & $16,886 \mathrm{a}$ & 16.85 \\
T2 & 60 & 1826 & 46.84 & $15,797 \mathrm{a}$ & 8.65 \\
T3 & 90 & 2822 & 17.85 & $18,832 \mathrm{a}$ & 7.18 \\
T3 & 120 & 3435 & 0 & $22,652 \mathrm{~b}$ & 6.59 \\
\hline
\end{tabular}

Another option is the irrigation scheduling according to so iltexture that permite optimization of wáter applied volumen avoiding over application or under application water. ${ }^{14}$ To apply this technologies it must to determine the soil physical-hydric properties (field capacity, permanent wilting point, bulk density) of soil horizons, as well as to know the crop coefficient $(\mathrm{Kc})$ and the potential evapo transpiration (ETo) by a auto matical weather station network.Besides, the mulching and shade netting decrease evapo transpiration (Figure 1).

\section{Technology transfer}

In irrigation thereis a déficit of policies of technology transfer that difficult the application of new technologies in the small farmers, so the efficiency of drip irrigation in the fieldis quite different from that obtained in experimental stations. ${ }^{15}$

This is a key factor to improve the hydric resource management , applying irrigation scheduling, soil wáter monitoring and pressure irrigation maintenance. In Chile, it was showed a low level of technology adoption, with only $30 \%$ of farmers adopting technologies and efficient irrigation systems (Figure 2). It should be highlight, that 
the adoption of technologies depends of education level, crops type, training system, being more important in crops more profitable as fruits , vine and horticultural. ${ }^{16}$

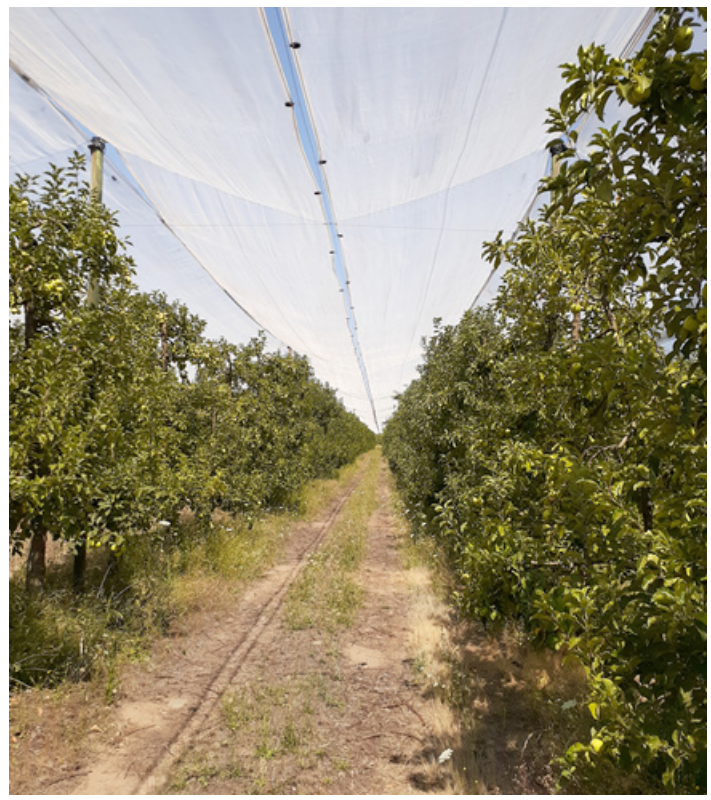

Figure I Shade netting in apple orchards, central zone of Chile.

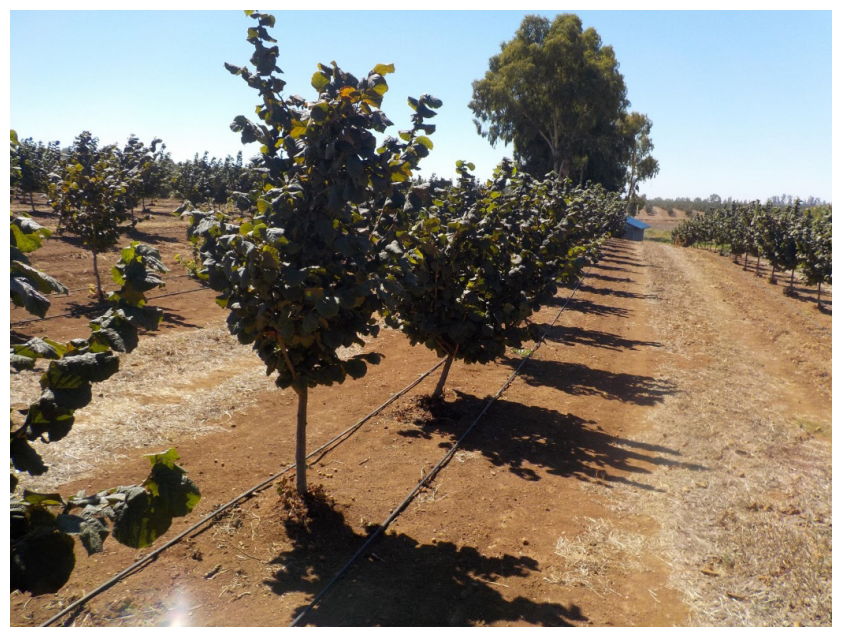

Figure 2 Drip-irrigated hazelnutorchard in a soil Argiaquollsat central southern of Chile.

Regarding to adoption of irrigation technologies, in Chile the farmers with hig her educational level, larger capital, credit access and extensión services are more likely to adopt modern irrigation. Credit access, extensión services seem to be more important in the change from traditional to modern irrigation. ${ }^{17}$

However, the small farmers are supported by the Agricultural Development Institute irrigation program (Figure 3) that fund upto $75 \%$ of construction Works with the aim of increase irrigation area, drip and sprinkler systems and improve irrigation efficiency (Figure 4).

\section{Climate change}

The climate change can cause great demands forwater in thefuture, and the increase the scarcity of wáter resources in many región of the world have intensifiedthesearchforstrategies to increase the water use efficiency. ${ }^{18,19}$

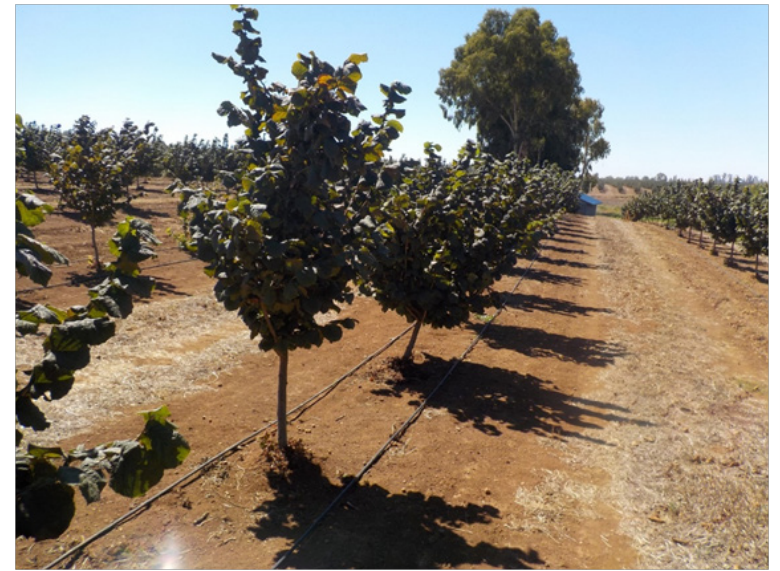

Figure 3 Irrigationand drainage law broadcast sign Mas y mejor riego para Chile.

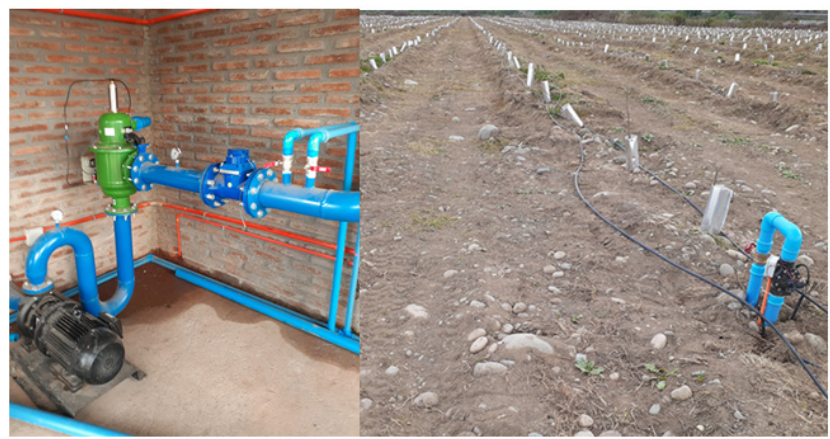

Figure 4 Drip irrigation project in cherry funded by law 18,450 of subsidie for irrigation and drainage works in alluvial soils of central zone of Chile.

The sustainability of agriculture in rain fed areas with low rain fallis problematic, because the uncertainties of the rain regimes introduce risk levels that endanger the viability of the rural company. In addition, the increases in the concentration of $\mathrm{CO} 2$ may affect the performance of the crops, being important a higher research in the water use and better explotation of rain fall. ${ }^{20}$

The climate change, is likely to increase temperature and reduce precipitation in all regions of the world, increasing drought risk and reduce crop yields. There by, adoption of more efficient irrigation technologies is key to diminush the water consumptive for the coming years.17. With continuous population and economic growth, wáter resources have become increasingly scarce in many countries and regions of the world..$^{18}$

\section{Water policy}

The public debate has focused on water resources and has giveng reat importance to the issue of water use efficiency (WUE). In this regard, the under pricing of irrigation wáter is frequently identified as a primary cause of excessive use of crop water. The wáter price can be a factor of regulation, higher prices can to have the potential to promote conservation but it is required changes in user behavior, as volumetric management by the irrigation organizatios and through policies that reduce the number of wells in use. ${ }^{21,22}$

Theoverallgovernmentpolicy in the countries is to promote a sustain able irrigated agriculture, that it be economically justified, financially viable, socially acceptable and technically approved 
without causing impact on the environment. It must also ensure that irrigation development programmes benefit as many farmers as possible and, in particular, those which belong to the most vulnerable groups of the rural community. ${ }^{23}$

The agricultura needs to increase production to meet population needs; but the productive soil and available wáter is declining. This must be supported by irrigation technologies that included rip, sprinklers, central pivot and micro-sprinkler irrigation. Besides .support programs will be needed to assist growers and managers in optimizing the allocation wáter among crops, selection of crops water balance, soil survey and automatic weather station networks. ${ }^{14}$

\section{Maintenance of irrigation system}

Localized irrigation methods have experimented a significant increase in area in Chile, as a result of subsidy programs for irrigation works and the need to improve water resource management. Pressurized irrigation represents a high initial investment, but after a years a malfunction is observed and in some cases, the collapse of the system due to maintenance problems.

High localized irrigation methods require a good agronomic and hydraulic design, good installation with quality materials and periodic maintenance to avoid clogging of the emitters that affect the uniformity of flows and pressures.

The lack of maintenance of the equipment and its components is the most frequent problem in pressurized irrigation. Operating and maintaining an irrigation installation helps the proper functioning of the system and to obtain a long useful life of the project. This it begins with a good project design that considers all the components of the system to avoid the entry of sediments into the irrigation network and continues with cleaning treatments, flow control and pressures, which allow the application of the projected volume of water to the plant to obtain high yields.

The operations that must be carried out are the installation of pre-filters, filters, after analyzing the physical and chemical quality of the water, pipes washing, whose main function is to prevent emitters clogging. And it continues with the pressure control and the determination of the flow uniformity coefficient, which must be greater than $90 \%$, and which is an indicator of the distribution efficiency on the surface irrigated by the emitters.

\section{Final considerations}

Water is a scarcing resource and the increase in crop production is key for supplying food to population always growing Today, irrigated agricultura is facing increasing competition with economy sectors and also with environmental organizations that consider the water a human right. Therefore, it's necesary to investigate and adopt management strategies of the soil-plant-water system to increase the yield of crops with significative saving water, considering engineering and agronomic management aspects that allow reducing the volumes of wáter applied. Besides, is required policy of technology transfer in irrigation and climate change for improve the application of new technologies between the small holders, because irrigation management decisisons can affect directly the water use efficiency. So, creating extensión programs to transfer of low-cost irrigation technologies and mitígate climate change is required, not only for farmers but also tour ban population of bigcities.

\section{Acknowledgments}

Authors want to thank to Farmers interviewed.

\section{Conflicts of interest}

Authors declare no conflicto of interest exists.

\section{References}

1. Pretty JN, Noble AD, Bossio D, et al. Resource-conserving agriculture increases yields in developing countries. Environ Sci Technol. 2006;40(4):1114-1119.

2. Barnett J, Webber M, Wang M, et al. Ten key questions about the management ow water in the Yellow River Basin. Environmental Management. 2006;38:179-188.

3. Battilani A, Dolezal F, Coutinho J, et al. Water use efficiency and dry matter accumulation in fertigated potatoes. Acta Hort. 2008;792:77-84.

4. Morison JIL, Baker NR, Mullineaux PM, et al. Improving water use crops productivity. Phil. Trans. R. Soc. Lond B Biol Sci. 2007;363(1491):639658

5. Rijsberman FR. Water scarcity: Fact or fiction?. Agric Water Manage. 2006;80(1-3):5-22.

6. Kiziloglu F, Sahin U, Kuslu Y, et al. Determining water-yield relationship, water use efficiency, crop and pan coefficients for silage maize in a semiarid region. Iriig Sci. 2009;27:129-137.

7. Faltenmerk M. Shift inthinding to address the 21 st century hunger gap:Moving focus from blue to green. Water Resour Manage. 2007;21(1):3-18.

8. Katerji N, Mastrorilli M, Rana G. Water use efficiency of crops cultivated in the Mediterranean region: Review and analysis. European Journal of Agronomy. 2008;28:493-507.

9. Fang QX, Ma L, Green TR, Yu, et al. Water resources and water use efficiency in the North China Palin: current status and agronomic management options. Agric Water Manage. 2010;97:1102-1116.

10. Boutraa T. Improvement of water use efficiency in irrigatedagriculture: Areview. Journal of Agronomy. 2010;9:1-8.

11. Jovanovic Z, Stikic R. Partial root-zone drying tehcnoque: from water saving to the improvement gof a fruit quality. Front Sustain Food Syst. 2018.

12. Reyes C. Requerimientos hídricos del olivo 'Arbequina' y su efecto en parámetros fisiológicos y productivos bajo riego por goteo. 2012.

13. Tesis Ingeniero Agrónomo, Facultad de Agronomía, Universidad de Concepción, Chile.

14. Evans RG, Sadler EJ. Methods and technologies to improve efficiency of water use. Water Resourc Res. 2008;44:1-15.

15. Benouniche M, Kuper M, Hammani A, et al. Making the user visible analysing irrigation practices and farmers logic to explain actual drip irrigation performance. Irrig Sci. 2014;32:405-420.

16. Jordan C, Speelman S. On farmad option of irrigation technologies in two irrigated valleys in Central Chile: The effect of relative abundance of water resources. Agric Water Manage. 2020;236:1-13.

17. SalazarC, Rand J. Production risk and adoption of irrigation technology: evidence from small-scale farmers in Chile. Last Am Econ Rev. 2016;25(2):2-37.

18. Nazer DW, Tilmant A, Mimi Z, et al. Optimizing irrigation water use in the West Bank, Palestine. Agric Water Manage. 2010;97:339-345.

19. Ward FA, Pulido-Velásquez M. Water conservation in irrigation can increase water use. Proceedings of the National Academy of Sciences. 2008;105:18215-18220.

20. Fereres E, Soriano MA. Deficit irrigation for reducing agricultural water use. Journal of Experimental Botany. 2007;58:147-159. 
21. Molle F. Water scarcity, prices and quotas: a review of evidence on irrigation volumetric pricing. Irrig Drainage Syst. 2009;23:43-58.

22. Venot JP, Molle F. Ground water depletion in the Jordan High lands: Can pricing policies regulate irrigation water use. Water Resourc Manage. 2008;22(12):1925-1941.
23. Palanisami K. Economic of irrigation technology transfer and adoption. 1997. 